\title{
A BRIEF History OF THE Trails OF GRAND TETON NATIONAL PARK
}

\author{
JAMES A. PRITCHARD \\ IOWA STATE UNIVERSITY $\downarrow$ AMES
}

\section{$\uparrow$ ABSTRACT}

This project investigated the history of the backcountry trail system in Grand Teton National Park (GTNP). In cooperation with GTNP Cultural Resources and the Western Center for Historic Preservation in GTNP, we located records describing the early development of the trail system. Only a few historical records describe or map the exact location of early trails, which prove useful when relocating trails today. The paper trail becomes quite rich, however, in revealing the story behind the practical development of Grand Teton National Park as it joined the National Park Service system.

\section{$\downarrow \quad$ INTRODUCTION}

Grand Teton National Park and its trail system developed together during the early years of National Park Service (NPS) administration. From the park's beginning, the trail system became an essential part of interpreting the park to the various factions of its public. Fritiof Fryxell's 1929 plan for the trails and his vision for interpreting the mountains to the public embodied the primary purposes of the NPS Division of Education.

Four main periods of trail building created the trail system in GTNP: the Forest Service period, the early period of planning and development of the newly established Grand Teton National Park, the Civilian Conservation Corps (CCC) era during the 1930s, and finally some additions during the MISSION 66 era. The trails we see and use today are an amalgamation of past periods. For example, many stream crossings in Cascade Canyon were reconstructed during the MISSION 66 era, but some of the stone stairs along the way from the boat dock to Hidden Falls date back to the CCC era.

Walking on a beautiful mountain path, one might never guess the extensive preparation of rock materials (expediting drainage) that is required before the surface "treadway" is laid down (Barter et al. 2006). In fact, trails are significant engineering achievements that need constant care and upkeep, including annual clearance of vegetation and the occasional repair to sections of trail.

\section{Pre-existing Trails}

Archeological sites are present in the upper parts of Berry Creek drainage, thought to represent "basecamps" occupied consistently over 8,000 years. A notable pre-historic travel route traversed the northern end of the Teton Range, from the west into the northern part of Jackson's Hole. Native Americans, fur trappers such as Osborne Russell in 1836, and finally explorers also traveled north and south through Jackson's Hole.

A few trails were established in and around the Teton Range before GTNP was established in 1929. The Teton Forest Reserve was originally established in 1897. The United States Department of Agriculture's Forest Service (USFS) held jurisdiction over the Teton Range and much of the surrounding area. Between 1897 and 1929, the United States Forest Service built several cabins on the east side of the Teton Range (e.g., Leigh Lake Patrol Cabin) to support patrols sent out to prevent timber trespass and to watch for forest fires. During the 1920s, a rivalry grew between the NPS and the 
USFS for appropriations, constituencies, and jurisdiction over Western lands (Rothman 1997). Expanding hiking trails in and near the Tetons would have helped the USFS make a case that it was incorporating recreation as well as managing timber.

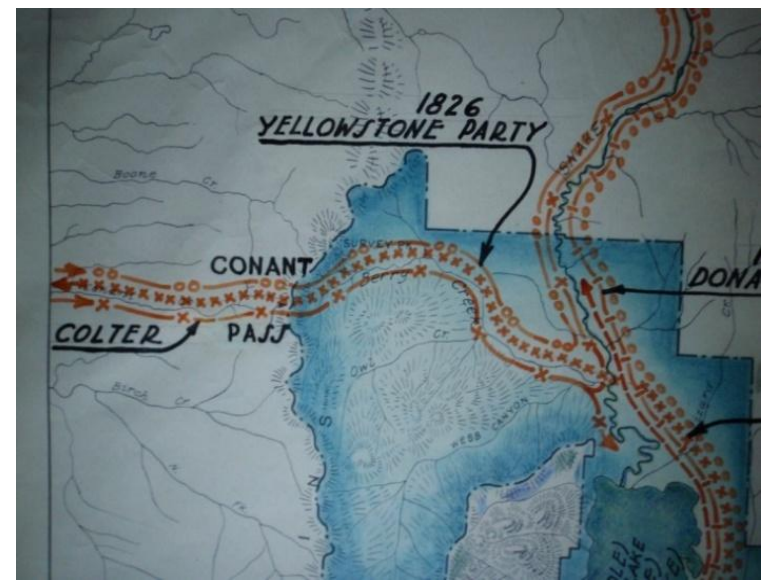

Figure 1. Maps from former interpretive displays depicted historical routes into Jackson's Hole. John Colter, as well as an 1826 exploring party, utilized a route frequented by Native Americans, up Berry Creek in the northern part of today's park.

The Pemble Trail was one of the earliest Forest Service trails in the valley. It was named for Robert Pemble, who homesteaded 160 acres on the Sane River, east of today's Moose-Wilson road. After 1900, the Forest Service built trail from Beaver Creek to the south side of Phelps Lake. An informal trail for horseback riding had been established up Death Canyon, and in 1921 the Forest Service improved the trail. Historian John Daugherty describes how a trail crew packed up a compressor to drill rocks for blasting. This trail went all the way to the divide at the top of the range (Daugherty 1999).

Maps of Teton National Forest drawn in 1928 and 1930 depict existing trails, although we don't know their level of maintenance (Figure 1). In 1929, existing trails in the area of GTNP at the time of its establishment included: 1) a trail northward from Teton Pass, into the southern end of the park and down Death Canyon, into the valley on the east side of the range where it assumed the name "Pemble Trail," ending at Stewart Ranger Station; 2) a trail in the northern part of the future park passing eastward over Conant Pass and down Berry Creek; 3) a trail along the north shore of Two Ocean Lake in the eastern part of the park (continuing eastward to Enos Lake); and 4) a trail along the west shore of Jackson Lake.

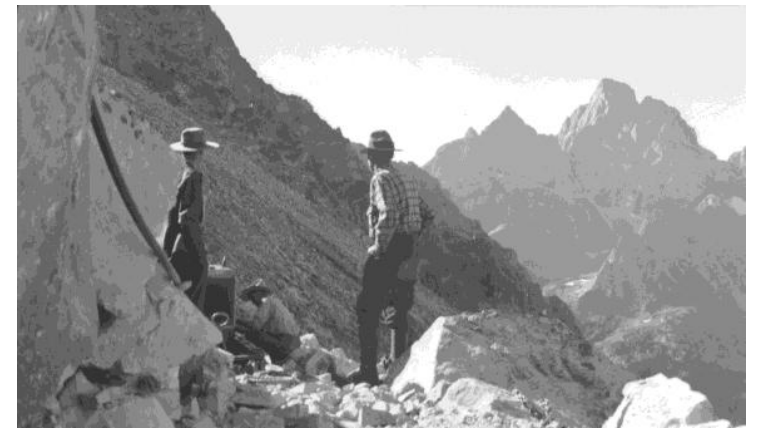

Figure 2. Trail construction often employed a compressor and drills used to fracture rocks or to prepare for blasting. This equipment was heavy, yet small compressors were conveyed far up the trail.

\section{Fryxell and the Trail System}

A coherent plan for a more extensive backcountry trail system in Grand Teton National Park was originally proposed by Fritiof M. Fryxell. He was employed during the academic year as a professor of geology at Augustana College, in Rock Island, Illinois. A competent mountaineer, Fryxell served as Grand Teton's first naturalist, established the park's natural history museum, and directed other naturalists through the summer of 1934 . His professional and recreational interests provided a synergy resulting in a strong basis for park development (Gerty 1986) (Figure 2).

In December of 1929, Fryxell submitted a plan titled "Report on an Educational Program, etc., for the Grand Teton National Park." The first major part of Fryxell's plan was trail development. His scheme suggested 5 divisions of trails: Lake Trails, The Piedmont Trail, The Canyon Spurs, The Divide Trail (later known as the Skyline Trail), and Peak Trails.

Fryxell's vision for trail development in Grand Teton National Park was coherent and enduring (Figure 3). The trail system has proved adequate and functional for serving various sorts of visitors through the present day. The development of trails proceeded very closely to the general plan Fryxell laid out. Significantly, his design included trails of varying difficulty. The valley trails invited visitors to a leisurely afternoon, while trails up the canyons opened up literally mountains of opportunity to both hikers and mountaineers. Shaped by the geography of the Teton Range, the trail system became essential to facilitating the sport of mountaineering throughout the range. 


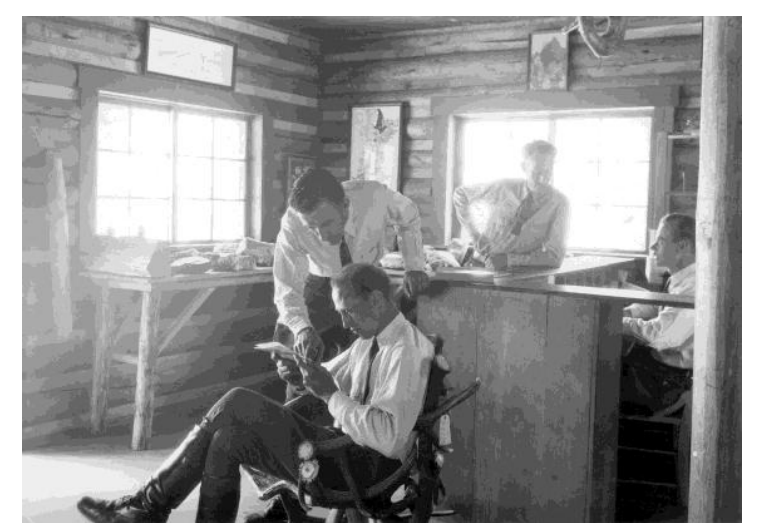

Figure 3. Fritiof Fryxell (seated) in the museum of Grand Teton National Park, c. 1930-1931. The naturalist staff was hired seasonally.

Fryxell, like a few other scientists of his day, played a significant role in the development of the national parks. Their visions for the parks ultimately shaped how parks portrayed nature to their public, and to some degree influenced how the National Park Service understood its mission. For many years, Fryxell was sought out for consultation by the NPS planning staff and Educational Division in San Francisco.

\section{Woodring's Hobby}

Samuel Woodring, GTNP's first superintendent from 1929 to 1934, supported Fryxell's plan and made trail construction one of the top priorities on his list (Figure 4). During the late summer of 1929, a small group of men traveled into the Teton Range with pack horses to scout out potential routes for a new trail, intended to be a primary attraction for the park. Secretary of the Interior Ray L. Wilbur took a personal interest in the progress of trail building in Grand Teton National Park, in particular what became known as the Skyline Trail. In 1930, the Superintendent reported 8 miles of trail building, and "a good beginning ... on what is to be known as the Skyline Trail which is to traverse the higher country connecting Leigh Canyon, to the north, and Death Canyon at the southern end of the park. The northern portion, beginning at Leigh Lake and skirting the west shore, has been completed well up into the canyon" (National Archives at College Park Center (NACP) Classified Files (CCF)).

A 1930 appropriation connected to the national Emergency Conservation Work (ECW) programs allowed Woodring to buy equipment and hire local crews for trail construction. With the 1931 appropriation, Woodring ordered a trail constructed around Jenny Lake, and the reconstruction of existing
USFS trails to Taggart Lake, Bradley Lake and Teton Glacier. Woodring called these trails "poorly located."

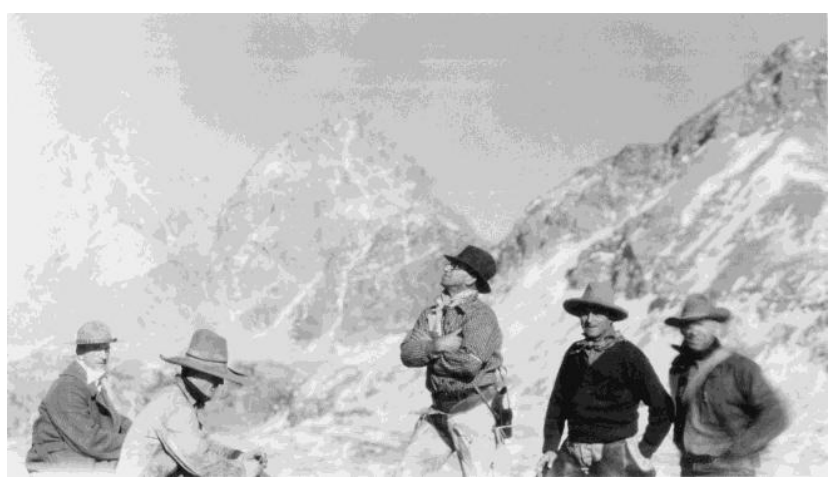

Figure 4. In 1929, newly appointed park Superintendent Samual Woodring (center) led a locating party into the Teton Range to map out potential trail routes.

The manpower and the budgets that came with the CCC camps enabled Woodring to build the trails that Fryxell had envisioned. During the early 1930s, trail development proceeded rapidly. In February of 1932, Woodring advised NPS Director Horace Albright (letters to Albright were invariably addressed "Dear Mr. Director") "You know, of course, that the Grand Teton trail system is my hobby, and that I am even more anxious than you are to complete an excellent system here" (CCF, NACP).

Woodring went on to note "this is primarily a trail park. The country traversed is very rough, and trail construction and maintenance costs are therefore high.... The mountains are steep and rugged and parts of the trails will be washed out each spring by streams from snowfields" (CCF, NACP). The fifty miles of trail built in 1931 would need maintenance

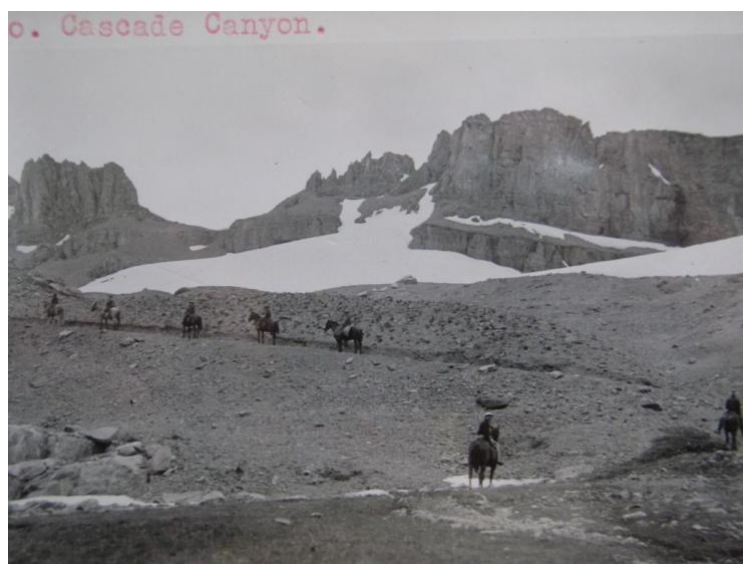

Figure 5. On the Skyline Trail (today's Teton Crest Trail), horseback riders near the head of South Fork of Cascade Canyon. Fryxell's vision and Woodring's enthusiastic development of park trails recognized a primary role for equestrian trail users. 
each year thereafter. The need for continuous upkeep meant job security for trail crews working each summer thereafter, including springtime clearing of scores of fallen trees.

Woodring never gave up his enthusiasm for building Grand Teton's trails (Figure5). In 1931, he injured his ankle while scouting trail locations in the park. Separated from the rest of his party, he crawled six hours to reach assistance, gaining a reputation as a heroic ranger in the process.

\section{The CCC and the loop trails}

The Civilian Conservation Corps (CCC) established five numbered camps in Grand Teton National Park during the Great Depression, making fundamental contributions to the infrastructure of the park. The CCC years comprised the glory days of trail construction in GTNP. In 1932, work started on the Death Canyon to Cascade Canyon loop trail. With a crew from the CCC, this loop was finished by the end of the 1934 construction season. Celebrated in the superintendent's annual report, the Death Canyon-Cascade Canyon trail comprised a 35 mile loop "traversing the most spectacular portions of the Teton Range" (Administrative Files, NACP).

From 1930 to 1938 , the CCC built trails at Alaska Basin, Phelps Lake, Moran Canyon, and Granite Canyon (Hubber and Caywood 1997). By 1938, the CCC had finished construction of the Indian Paintbrush Trail. Superintendent Thomas E. Whitcraft (1936-1940) noted that "a number of swaddle horse parties have taken the fine trip this trial makes possible" (Administrative Files, NACP).

Trails need to be constructed in stout fashion, especially in a mountainous environment where the geological forces of nature are in constant flux. Erosion, snowmelt and rockfall comprise the more obvious forces at work. Although the CCC had finished the Avalanche Canyon section of the Skyline Trail in 1933, it soon became apparent that one trail segment needed to be rebuilt. Superintendent Whitcraft wrote about "the perplexing problem annually represented by this 'Wall Trail', since its completion in 1933 (Figure 6). It has been necessary because of the danger involved, to close this section of trail to travel the past two seasons [1937-38]." In August 1938, Superintendent Whitcraft noted "A CCC Spike Camp (Figure 7) supervised by regular personnel has made good progress on the realignment of the Skyline Trail in South Cascade Canyon, and with favorable weather conditions this project involving the construction of a trail around the 'Wall' at the head of Avalanche Canyon, will be completed during the current season ..." (AF, NACP).

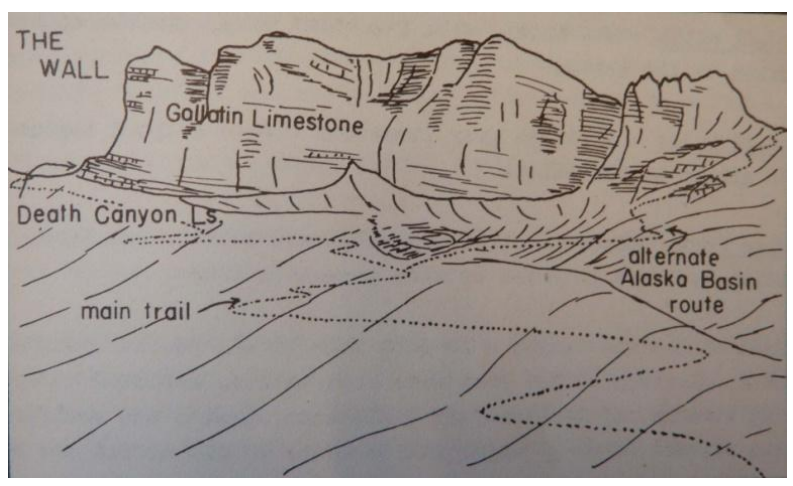

Figure 6. Howard R. Stagner's 1938 “A Naturalist's Guide to Grand Teton National Park" depicted the main trail route under The Wall at the head of S. Fk. Cascade Canyon. Shortly thereafter, the alternate route into Alaska Basin was designated the new trail location.

\section{The Limits of Trail Development}

This intensive phase of trail development was not embraced by everyone in or out of the NPS. It is significant that park planning during this time period involved personnel from the Educational Division as well as landscape architects in the Engineering Division at the NPS Field Office based in San Francisco, California. In 1933, the NPS regional landscape architect wrote a memo, suggesting that the ambitious program of trail construction was causing more damage than he was comfortable with (Hubber and Caywood 1997).

The staff at Grand Teton Park also experienced some divisions regarding trail development. There is evidence that NPS rangernaturalist Raymond T. Cutter or Fritiof Fryxell experienced some conflict with Superintendent Woodring on this subject. In a cryptic note found in the archives, we find this criticism of Woodring: "He has one hobby-trail building-now more miles of trails than can be kept up." Ranger Phil Smith, Fryxell's main climbing partner, was of a similar opinion (Fryxell Papers, AHC). Overall, we get the sense that NPS officials differed on how to keep the primitive character of the Teton Range intact, while effectively administering the park.

Despite his enthusiasm for developing the park, Woodring also accepted the overall conceptual spirit of Fryxell's plan. In a 1930 letter to Chief Engineer Frank A. Kittredge, NPS Director Horace Albright noted "Woodring states that he does not believe we should construct a trail up Taggart 
Canyon ... . 'We must leave one of the larger canyons for our adventurers and alpine climbers" (CCF, NACP).

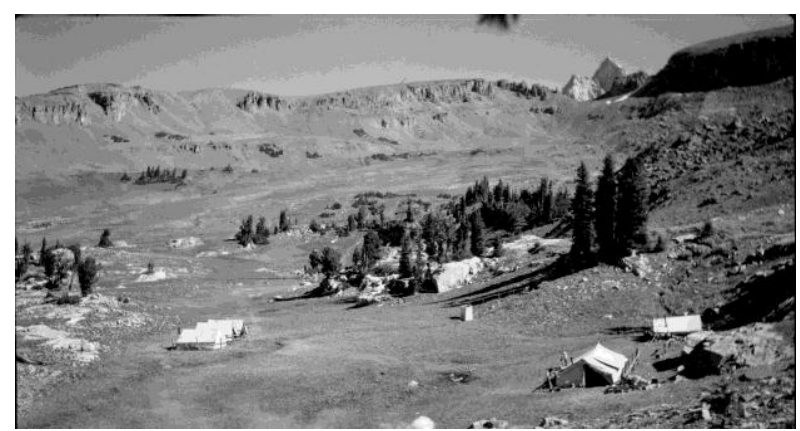

Figure 7. Spike camp for trail construction crew in the high country of Grand Teton National Park.

Much of the trail system in Grand Teton was constructed with horseback riding in mind. Woodring himself enjoyed riding, and the ranger staff regularly used horses to get around the park. By 1938, almost 85 miles of trails had been constructed in Grand Teton National Park. These were the essence of the park's trail system, the rugged mountain trails into the heart of a climber's wonderland.

\section{Master Plans}

The extent of park development comprised a central issue for the Park Service in the 1930s. Most of the national parks started formulating master plans during the early 1930s, using a planning process initiated by Thomas Chalmers Vint and others in the NPS Landscape Division (Figure8). As historian Linda Flint McClelland (1998) writes, this process integrated the landscape programs of individual parks "into a single, fully orchestrated process of park planning and development ....."The Landscape Division worked out of NPS Field Headquarters offices in San Francisco, California, where staff participated in a synergistic relationship with the NPS Educational Division.

Throughout the 1930s, staff at Grand Teton and the Landscape Division (which in 1934 was renamed the Branch of Plans and Design) differed on the issue of building barns and patrol cabins in remote locations. The disagreement went beyond budget, centering on development in the Teton backcountry. In 1938, Superintendent Whitcraft advised the NPS regional director that housing trail crews in tents was ineffective in "a Park of this nature, which is subject to very heavy snowfall, periods of heavy rain" and a short tourist season (Administrative Files, NACP). The superintendent advocated patrol cabins to house the trail crews, allowing more time on the trail and greater convenience of access for ranger patrols, trail and fire crews. The Landscape Division, on the other hand, preferred to err on the side of limiting development to maintain a primitive feel in the backcountry.

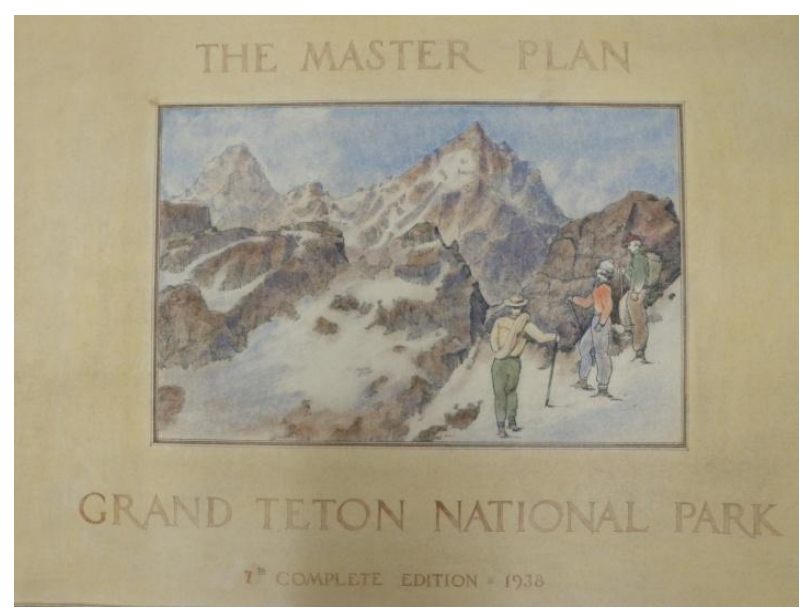

Figure 8. Master Plans were an essential element for overall planning and for budgeting. The plan for Grand Teton recognized the role of equestrian, mountaineering, and hiking based recreation. Courtesy National Archives at College Park, MD.

In 1940, architect Howard W. Baker (NPS Branch of Plans and Design) cautioned against the over-development of the GTNP trail system. The developed trails should not "be made easy for everyone, but remain as an adventure to mountain climbers." Baker also suggested that "patrol cabins should not be constructed in too many places and wherever possible we ought to cooperate with the Forest Service and have them patrol from the West" (AF, NACP). Cooperation did not develop to that extent, as patrolling officers stopped at the jurisdictional boundaries.

The NPS Field Headquarters played a significant role in standardizing and in facilitating park development for the entire system. In April of 1932, Acting Chief Engineer A.W. Burney sent out trail development programs to Sequoia, Yellowstone, Mt. Rainier, and Grand Canyon National Parks. In 1933, GTNP submitted its own six-year park development and construction program, incorporating Fryxell's design for the trail system. Park staff revised these programs along the way, using them alongside the budgeting process to plan the development of visitor facilities. Some proposed projects never came to completion, such as a trail maintenance cabin near the head of Indian Paintbrush Canyon, an element of the 1935-40 plan. 


\section{The 1940s}

During the 1940s, the trail system revolved around paths radiating out of park headquarters at Beaver Creek (just north of Moose, Wyoming) and from the Jenny Lake Museum. Existing trails up Berry Creek in the North District and the trail to Enos Lake along the north shore of Two Ocean Lake were not advertised to the general public on a 1947 map of the park's trails.

By 1941, GTNP Park staff considered the trail system complete. On July 29, 1941, GTNP Superintendent Charles J. Smith wrote the Director: "No addition to the present and approved trail system is recommended . . . and every effort should be continued to retain the Teton Mountain Region as a wilderness" (Administrative Files, NACP).

Keeping trails open for public use continued to present challenges(Figure 4). In 1948, Grand Teton Superintendant John S. McLaughlin noted that the "Paintbrush Canyon-Cascade Trail has not been open to the public since 1941 " due to a lack of funds to hire enough trail crew to clear "the upper reaches of the trail of slides and snow" (Administrative Files, NACP).

\section{MISSION 66 Era Trails}

The final pulse of trail building in Grand Teton came with the large-scale visioning and park system improvement project known as MISSION 66. A description of proposed projects for GTNP noted that over the years, "many of the trails (built by the CCC in the 30's) have deteriorated, some are now unfit for travel, or are beyond recognition as trails. Much new construction work is needed to bring the existing trails back to par, and to rebuild some of the trails that have been neglected over the years" (Historic Records Collection, GTNP Archives).

During the late 1950s and early 1960s, GTNP added trails near the new visitor facilities at Colter Bay, at Signal Mountain, and near Jackson Lake Lodge. Few records documenting this period of trail development have survived.

In 1955, construction of the new Jackson Lake Lodge and the cabins huddled around it came to completion, creating a clear need for easilyaccessible recreational hiking trails. Nearby, scenic Emma Matilda and Two Ocean Lakes provided a logical destination for hikers staying at the lodge. These paths built upon one pre-existing trail (shown in a tourist map attached to the 1932 park circular) passing the northern shore of Two Ocean Lake, and bending northeast to follow Pacific Creek up to Enos Lake in Teton National Forest. In 1957 construction budgets, staff reported this loop trail $30 \%$ complete.

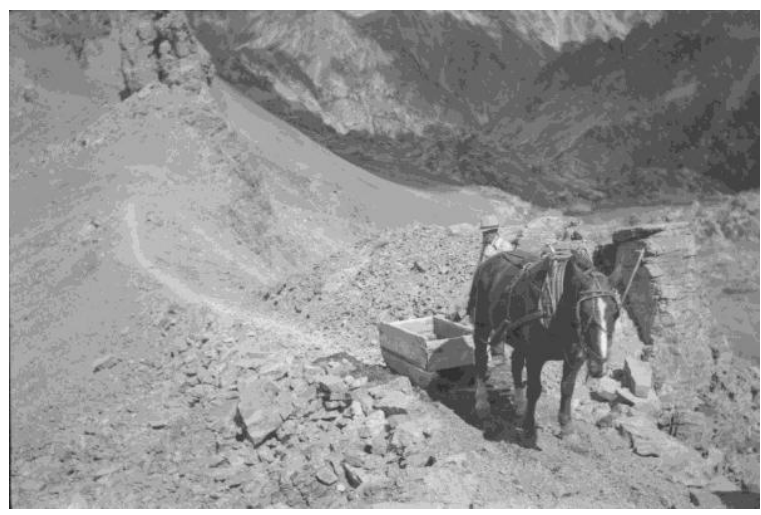

Figure 9. Horses accomplished a great deal of trail work in the high country.

\section{Managing the backcountry}

During the 1970s, park staff wrote the first Backcountry Management Plan for Grand Teton NP. By the later 1970s, the park started to receive numerous complaints about horses on the trails and the flies that people associated with horses and their droppings. Clearly, a significant change was underway in the number of hikers relative to equestrian trail users.

In 1989, park staff finished a significant revision to the Backcountry Management Plan. This plan divided the trails in the park into five zones. Leigh Canyon served as a dividing line between gateway trails and trail corridors in the South District, and more primitive trails in the North District where hikers could experience "near pristine" areas. The 1976 master plan and the 1989 Backcountry management plan discussed the North District Trails in terms of a more adventurous, primitive, or wilderness-oriented outing.

Planning staff noted in 1987 that of 2.25 million annual visitors to Grand Teton NP, about 165,000 people hiked in the backcountry, where about 25,000 camper nights needed accommodation, along with 8,000 climber overnights. In 1986, at Hidden Falls the day hiker load was up to 370 people per hour. On a busy day, 70 to 90 people hiked to Lake Solitude, illustrating the report's concern that "high elevation lakes are destinations for enough day hikers to cause significant impacts at Marion, Surprise, Laurel, and Holly Lakes and Lake Solitude." The trail system initiated by Fryxell and 
Woodring began to meet its limits in accommodating so many visitors.

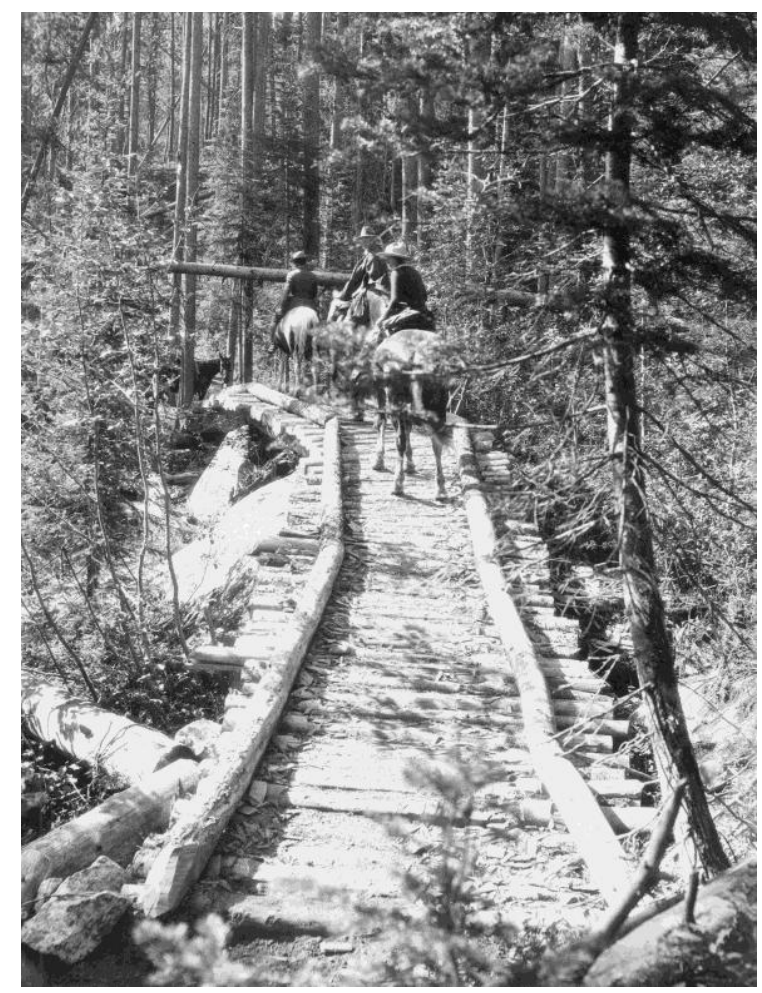

Figure 10. Trail building also meant facilitating passage across rivers and over wet places. CCC trail crews took pride in constructing bridges and other rustic crossings. By the time of MISSION 66, many of these features needed rebuilding.

\section{Historical reviews of NPS trails}

Park engineering staff surveyed and documented the trail system at GTNP, notably from 1936-38 and in 1986. Two valuable reports document additional specific details about the trails of Grand Teton and their historical context. In 1989, Steven Mehls and Carol Drake Mehls submitted a "Historic Transportation Survey" for GTNP, containing an exhaustive listing and description of trails with their constructed features including footbridges and culverts (Figure 10). Thanks to that assessment, by 1995 GTNP and the Wyoming State Historical Preservation Office were communicating regarding potential listing on the National Historic Register for the Bradley Lake Trail, Cascade Canyon Tr., Death Canyon Tr., Jenny Lake Tr., Leigh Lake Tr., N. Fk. Cascade Can. Tr., Paintbrush Canyon Tr., S. Fk. Cascade Canyon Tr., String Lake Tr., Taggart Lake Tr., Teton Crest Tr., and the Valley Trail. Since that time, the physical integrity of trails remained an essential issue. As Mehls noted, "on-going work to correct problems caused by the extreme environment has led to the nearly complete rebuilding of the system again during the past twenty years. As a result no man-made features remain on the present trails that are more than fifty years old" (Mehls and Mehls 1989).

A wealth of technical detail on trail reconstruction techniques can be found in Christian S. Barter et al., "Acadia Trails Treatment Plan." Finally, a more extensive version of this report will be deposited with the archives at Grand Teton National Park.

\section{$\uparrow \quad$ ACKNOWLEDGEMENTS}

This study was funded by the University of Wyoming- National Park Service Research Center, Laramie, Wyoming. Photos and map courtesy Grand Teton National Park Archives, except Fig. 9, courtesy National Archives and Records Administration at College Park, College Park, MD. Thanks go out to Alice Hart, cultural resources curator at GTNP; Brian Bergsma, Trails Supervisor at GTNP; Jamie Schoen, archeologist with the Bridger-Teton National Forest; the archivists and staff at the American Heritage Center, University of Wyoming, the National Archives at College Park, Maryland, and at the Yellowstone National Park Archives.

\section{$\uparrow \quad$ Literature Cited}

Barrick KA. 2008. Harrison R. Crandall: Artist, pioneer and patron of Grand Teton National Park. In: Harlow HJ, editor. University of Wyoming-National Park Service Research Center, Grand Teton National Park, 30th Annual Report. 2006 \& 2007. p. 19-29.

Bonney OH, Bonney LG. 1992. The Grand controversy: The pioneer climbs in the Teton Range and the controversial first ascent of the Grand Teton. New York: The AAC Press.

Bridger-Teton National Forest, Archaeologist's Office, Jackson, Wyoming.

Fryxell Papers, American Heritage Center, University of Wyoming, Laramie, Wyoming. Records cited are from Box 4. 
62

National Archives at College Park, College Park, Maryland (NACP). Records cited are from Record Group 79, Entry 10 Central Classified Files (CCF), Boxes 288, 289 \& 300; Entry 11 Administrative Files (AF), Boxes 1049, 1053 \& 1054.

NPS (U.S. National Park Service). 2000. The Civilian Conservation Corps and the National Park Service, 1933-1942: An administrative history. U.S. National Park Service, ParkNet. Available from: http://www.nps.gov/ history/history/online_books/ccc/ccc2.htm.

NPS (U.S. National Park Service). 2006. Historic listings of National Park Service officials. U.S. National Park Service, ParkNet. Available from: http://www.nps.gov/history/online books/to $\underline{\text { lson/histlist7g.htm }}$
NPS (U.S. National Park Service). 2007. Menors Ferry Historic District. U.S. National Park Service. Available from: http://www.nps.gov/grte/historyculture/men ors.htm.

Pritchard JA. 2009. The northern backcountry patrol cabins of Grand Teton National Park. Available from: www.public.iastate.edu/ jpritch/homepage files/GTNPCabinReport.pdf. 